PROPOSTA DE DEMONSTRAÇÃO TÉCNICA

\title{
Da roda e brincadeiras populares como metodologias para o trabalho energético do ator de rua
}

\author{
Orientadora: Profa ${ }^{\mathrm{a}} \mathrm{Dr}^{\mathrm{a}}$ Michelle Cabral \\ SARAIVA, Eduarda ${ }^{1}$; ATAIDES, Luziheidy ${ }^{2}$ \\ Graduação, curso de Teatro Licenciatura - Universidade Federal do Maranhão \\ Eduardamilena04@gmail.com¹; heidyataides@gmail.com².
}

\section{RESUMO:}

O trabalho em questão vem apresentar o desenvolvimento da pesquisa que teve continuidade a partir da experiência inicial na disciplina Teatro de Rua, ministrada pela Professora Doutora Michelle Cabral, no curso de Teatro - UFMA. Trata-se do preparo/treinamento do ator para a cena do teatro de rua a partir das rodas de canções populares brasileiras e maranhenses. O estudo, precedido de alongamento e aquecimento físico e vocal, trás a tona a roda com percussividade, cantigas e movimentos em uma dança circular e energética características. A percepção inicial e a motivação para a continuidade da pesquisa deu-se a partir do resultado visto no desenvolvimento de atores em cenas do espetáculo teatral de rua “O Tribunal”, produto artístico final da disciplina supracitada e cursada no semestre 2017.2. A demonstração técnica colocará em prática alguns dos exercícios em roda, no qual necessitará da participação dos presentes, e também contará com exposição oral, dando referência a alguns dos teóricos que utilizamos para aprofundar as linhas gerais desse fazer artístico no qual tem o foco na preparação do ator.

PALAVRA CHAVE: Voz. Corpo. Roda. Teatro de rua, Cultura popular. 


\section{INTRODUÇÃO}

A Demonstração Técnica tem como objetivo a exposição teórica e a prática dos exercícios técnicos vocais e corporais com os participantes do evento. O desenvolvimento do trabalho tem a canção e a brincadeira popular de forma coletiva e em roda, e compõe de exercícios alinhados para preparação do ator para a cena na rua.

A demonstração é o resultado de pesquisa realizada a partir da experiência inicial na disciplina Teatro de Rua, ministrada pela Professora Doutora Michelle Cabral, no curso de Teatro - UFMA e tem como foco apresentar métodos que trabalham técnicas vocais e corporais, estes que estiveram intimamente imbricados para com a proposta do jogo das brincadeiras populares, resgates brincantes e dançantes da nossa cultua popular como preparo energético do ator de rua, a partir da necessidade de treinar esse ator para o potencial desempenho artístico e criativo deste nos espaços urbanos, superando assim características/obstáculos diversos, tais como, a polifonia da cidade e seu fluxo caótico cotidiano, suas múltiplas interferências, a necessidade de cativar/afetar o público para o acontecimento espetacular de rua, entendendo tais características da rua, não apenas pelo viés do percalços da mesma, mas como narrativas do espaço, do lugar em que se está, com as quais o ator de rua deve superar e agregar como possibilidades para um desenvolvimento do seu trabalho artístico, considerando todas as amplitudes de espaços e outros supostos desafios que acompanham esses lugares natural e continuamente.

O que pretendemos analisar são os resultados positivos da nossa proposta de trabalho/aquecimento/jogo que experimentamos em sala no processo colaborativo do espetáculo “O Tribunal”, apresentado a partir da disciplina Teatro de Rua ministrada pela Prof ${ }^{a}$ Dr $^{\mathrm{a}}$ Michelle Cabral, e expor a continuidade das nossas pesquisas, uma vez abertos os caminhos e nossas percepções a respeito das práticas das rodas cantadas e dançadas como caminhos para um estado de presença e energia dos atores de rua. 


\section{METODOLOGIA/DESCRIÇÃO}

Tendo como referência Guimarães e Lopes (2016, p.80,81), vamos nos apoiar no despertar de três das setes matrizes que desenvolveram no grupo “Quem tem boca é pra gritar”.

Estas são: Matriz música, matriz corpo e matriz jogo.

Primeiramente partiremos de um alongamento mais trabalho de respiração diafragmática e intercostal, para um primeiro despertar do corpo.

Em todo o processo, a musicalidade estará presente, para tanto, teremos como aliados exercícios de relaxamento musculares e posteriormente vocais, uma vez que pretendemos um primeiro desbloqueamento do corpo, para um melhor trabalho vocal e consequentemente uma melhor emissão vocal.

O Canto virá após estes trabalhos de relaxamento, no qual canções serão compartilhadas/ensinadas juntamente com os movimentos atrelados a elas, estas que virão com acompanhamento percussivo de caixas do divino, trazendo ritmos do cacuriá e do côco, para a formação da roda e deslocamento circulares dos brincantes-dançantescantantes.

\section{ANÁLISE/CONSIDERAÇÕES}

A experiência que tivemos na disciplina Teatro de Rua, onde encontramos no jogo da roda do cancioneiro popular, das cantigas de roda, um caminho, um método, para chegarmos a um estado que chamamos de estado energético essencial para adentrarmos à rua, foi essencial para um despertar para esta pesquisa a qual pretende preparar energeticamente o ator de rua para a rua, na qual este se defrontará com a roda, a comunidade formando ao seu redor.

Entendemos que o teatro de rua se faz como uma comunidade que se atravessa e se coloca diante de outra para estabelecer diálogos, afetos, questionamentos, emoções, enquanto comunidade vemos um povo reunido ao redor do acontecimento espetacular, como diz Guenóun: O Teatro requer um público, coletivo, efetivamente reunido. É modo, determinado, de sua apresentação (GUENÓUN,p.13).

Convocamos o público e a este convidamos à roda com a presença espetacular do teatro de rua: 
Este publico quer ter o sentimento concreto, de sua existência coletiva. Quer perceber suas próprias reações, as emoções que o percorrem, o contágio do riso, da aflição, da perspectiva. É uma reunião voluntária, fundada sobre uma divisão, é ao menos como esperança, como sonho, uma comunidade. (GUENÓUN,p.21)

Adentramos à rua ressignificando o espaço e dando possibilidade de fruição e reconhecimento do teatro como um lugar comum à todos, como um diálogo com a comunidade.

\section{BIBLIOGRÁFICAS}

GUENÓUN, Denis, A Exibição das Palávras: Uma idéia(política) do teatro. Rio de Janeiro. Teatro do pequeno gesto, 2003

TURLE, Licko, TRINDADE, Jussara, GOMES, Vanéssia. TEATRO DE RUA Discurssos, pensamentos e memórias em rede. Fortaleza: Aldeia Casa Viva, 2016. $1^{\text {o }}$ Edição 